\title{
Characteristics and Prevention of the Debris Flows following Wenchuan Earthquake in Jushui River Basin, An County, China
}

\author{
Yonggang Ge, ${ }^{1,2}$ Jianqiang Zhang, ${ }^{1,2}$ and Xiaojun Guo ${ }^{1,2}$ \\ ${ }^{1}$ Key Laboratory of Mountain Hazards and Earth Surface Processes, Chinese Academy of Sciences, Chengdu 610041, China \\ ${ }^{2}$ Institute of Mountain Hazards and Environment, Chinese Academy of Sciences, Chengdu 610041, China \\ Correspondence should be addressed to Yonggang Ge; gyg@imde.ac.cn
}

Received 19 April 2014; Revised 17 September 2014; Accepted 18 September 2014; Published 17 December 2014

Academic Editor: Jianshe Lei

Copyright (c) 2014 Yonggang Ge et al. This is an open access article distributed under the Creative Commons Attribution License, which permits unrestricted use, distribution, and reproduction in any medium, provided the original work is properly cited.

\begin{abstract}
After analysing the catastrophic debris flows on August 18, 2012, and on July 9, 2013, in Jushui River basin, An County, the Wenchuan Earthquake seriously striken areas, it was found that they were characterized by the clay soil content of $0.1 \sim 1.2 \%$, the density of $1.68 \sim 2.03 \mathrm{t} / \mathrm{m}^{3}$, the discharges of $62.2 \mathrm{~m}^{3} / \mathrm{s}$ to $552.5 \mathrm{~m}^{3} / \mathrm{s}$, and the sediment delivery modulus of $1.0 \sim 9.4 \times 10^{4} \mathrm{~m}^{3} / \mathrm{km}^{2}$. Due to intense rainstorm, many large debris flows produced hazard chain, involved in flash flood, debris flow, dammed lake, and outburst flood, and rose Jushui River channel about $1 \sim 4 \mathrm{~m}$ as well as amplified flood. The hazards and losses mainly originated from the burying and scouring of debris flows, flood inundating, and river channel rise. The prevention of debris flows is facing the intractable problems including potential hazard identification, overstandard debris flow control, control constructions destructing, and river channel rapid rise. Therefore, the prevention measures for the basin, including hazard identification and risk assessment, inhabitants relocating, monitoring and alarming network establishing, emergency plans founding, and river channel renovating, and the integrated control mode for watershed based on regulating the process of debris flow discharge, were recommended for mitigation.
\end{abstract}

\section{Introduction}

Debris flow, an abrupt earth surface phenomenon, extensively and frequently occurs at mountain areas with steep terrain, quantity of unconsolidated soil, and abundant surface runoff. It is often exasperated by extreme rainstorms, intensive exploitation activities, and intensive earthquakes. Due to quantity of loose soil accumulation, the debris flow following intense earthquake generally expresses different characteristics to those before the earthquake. The debris flows following Wenchuan Earthquake are characterized by lower triggering rainfall threshold, high density, higher velocity, larger discharge, bigger magnitude, and intensive impact and impose the heaviest-dangerous hazards on local living and reconstructions at the seriously stricken areas $[1,2]$. The noticed catastrophic debris flows, including the ones on September 24, 2008, at Beichuan County [3], on August 13 and 14, 2010, at Wenchuan, Dujiangyan, and Mianzhu [4], on July 3, 2011, at Wenhuan Chuan [5], on August 18, 2012, at Pengzhou [6] and An County, and the ones on July 9-10, 2013, at the whole earthquake areas, not only made huge properties losses and casualties but also produced new challenges and requirements for measures and technologies of mitigation due to the breaches of most control constructions, which were constructed according to the present national standard. Debris flows will be very active in the beginning 10 20 years after this intensive earthquake [7]. The exploration of rational and optimizing prevention measures, according to the changed formation conditions, characteristics, and hazard patterns of these debris flows, plays important role in debris flow hazards mitigating and reconstructing. The catastrophic debris flows and their following flash floods on August 18, 2012, and July 9, 2013, strongly stroke the upstream of Jushui River basin (Gaochuan Town), An County, Sichuan Province, and made huge damages on buildings, houses, highway, human, and prevention constructions. This work aims to discuss the problems of debris flow control and explore rational solutions for this basin, which also contribute to the mitigation of debris flows in the whole seriously stricken areas. 


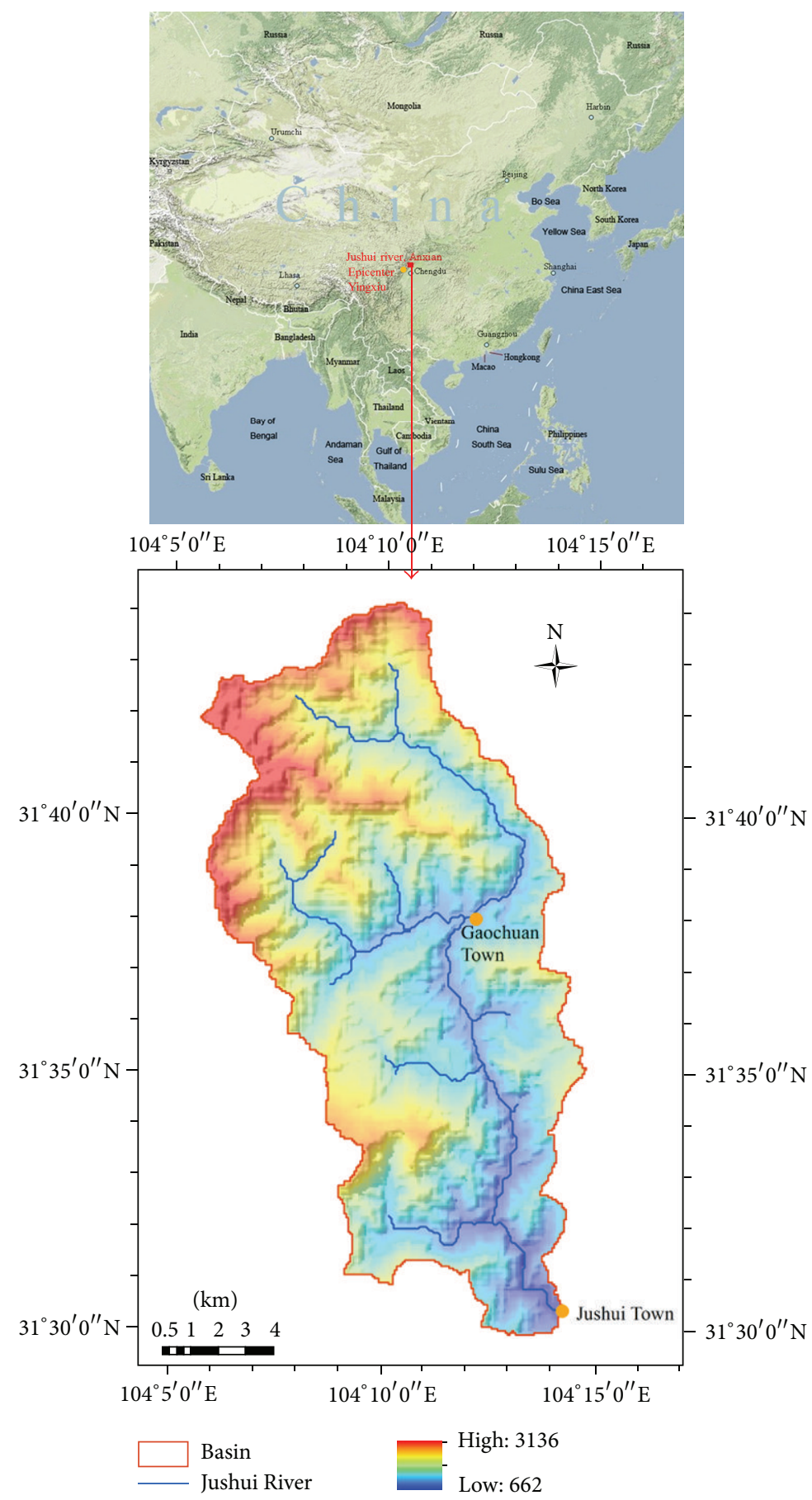

FIGURE 1: Location of Jushui River basin.

\section{Study Area}

Jushui River, a tributary of Fu River, is located at the western An County, Sichuan Province, China. The area is about $222 \mathrm{~km}^{2}$ (N 31 $29^{\prime} 22^{\prime \prime} \sim 31^{\circ} 42^{\prime} 36^{\prime \prime}$, E $\left.104^{\circ} 05^{\prime} 51^{\prime \prime} \sim 104^{\circ} 15^{\prime} 14^{\prime \prime}\right)$, the channel of river is $33.5 \mathrm{~km}$, and the elevation difference reaches $2474 \mathrm{~m}$ with the highest of $3136 \mathrm{~m}$ and the lowest of $662 \mathrm{~m}$ (Figure 1). The active faults, including YingxiuBeichuan faults and Dujiangyan-Jiangyou faults, and their sub-faults pass through this region. The upthrust movements of faults with the aspect from west-north to east-south generate imbricated fabric zone. The distance from Gaochuan Town to Yingxiu Town, Wenchuan County, the epicenter of the Wenchuan Earthquake, is about $95 \mathrm{~km}$. Except for the stratum of Tertiary, almost all those from Paleozoic to Cenozoic develop and limestone, dolomite, dolomitic limestone, sandstone, mudstone, siltstone, argillaceous limestone, shale, phyllite, and Pleistocene deposits occupied this region. 
Semitropical humid climate, with the annual precipitation of 1200 1400 mm, occurring from June to September by many rainstorms, covers Jushui River basin. Before the Wenchuan Earthquake, flash flood frequently occurred but only several debris flow sites, the watersheds of Gan, Daoxi, Dongzi, and Sancha with the reoccurrence period of several decade years. Because the Yingxiu-Beichuan faults, the triggering faults of the Wenchuan Earthquake, pass through this basin, rock falls and landslides extensively formed at the hardrock areas and at the soft-rock areas, respectively, with the density of 15 sites $/ \mathrm{km}^{2}$ [8], and unstable slopes densely distributed in the steep mountains after the earthquake. They prepared abundant loose sediments for debris flows. Due to abundant loose soil and sediment, favorable rainfall, and steep geomorphology, debris flows became very active, occurred in almost gullies and watersheds, and imposed huge threats on local people and reconstructions. The disastrous ones took place on July 17, 2011, August 18, 2012, and July 9, 2013 , and the last two ones made huge losses in whole basin.

\section{Methodologies}

The remote sense image with $4 \mathrm{~m}$ resolution from Google Earth and the data of DEM with 1:50000 were used to get the geomorphologic parameters of Jushui River and its typical watersheds for the calculation and estimation of discharges of flash flood. The local observation rainfall data from Gaochuan Town and its adjacent areas were used to analyze the triggering condition of debris flow and flash flood. 14 samples of debris flow deposit were collected in field investigation to test particle size distribution and then to analyze the characteristics of debris flows. The velocity and discharge of debris flow were calculated using the survey data of cross-sections at 8 watersheds and then their magnitude were estimated by the methodology of rainstorm-flood and the data of debris flow deposits. The discharges of flash flood of river channel at 4 sections were calculated by the Manning formula based on the field survey data including the depth of flash flood, the area of cross-section, and the slope gradient of river channel.

3.1. Debris Flow Size Distribution and Density. 14 debris flow deposit samples, with the size up to $100 \mathrm{~mm}$, were collected in field investigation in 2012 and 2013. They were dried and sieved and then some part, with the size of less than $0.5 \mathrm{~mm}$, was measured using laser granularity meter to obtain particle size distribution. Furthermore, the formula of debris flow density, established by $\mathrm{Yu}$ [9], was adopted and shown as follows:

$$
\gamma_{D}=\gamma_{0}+P_{2} P_{0.05}^{0.35} \gamma_{V}
$$

In the formula (1), $\gamma_{D}$ indicates the density of debris flow, $\gamma_{0}=1.5 \mathrm{t} / \mathrm{m}^{3}$ is the lowest density of debris flow, $\gamma_{V}=2.0 \mathrm{t} / \mathrm{m}^{3}$ is the lowest density of viscous debris flow, and $P_{2}$ and $P_{0.05}$ are the percentage of debris flow materials with over $2 \mathrm{~mm}$ and less than $0.05 \mathrm{~mm}$, respectively.

\subsection{Debris Flow Velocity and Discharge}

3.2.1. Cross-Section Methodology. The parameters of eight cross-sections of debris flow discharge at the straight and less tortuous channel sections were measured using laser distance meter in field investigation to calculate the velocity and discharge of debris flows. The formula of the velocity and discharge of debris flow is shown as follows [10]:

$$
\begin{aligned}
V_{C} & =\frac{1}{n_{c}} H^{2 / 3} I^{1 / 2}, \\
Q_{C} & =W_{C} V_{C} .
\end{aligned}
$$

In the formula (2), $V_{C}$ is the velocity of debris flow, $n_{c}$ is the roughness coefficient of watershed channel and $H$ is the depth of debris flow, $I$ is the slope gradient of watershed channel, $Q_{C}$ is the peak discharge of debris flow, and $W_{C}$ is the area of debris flow section. The value of $n_{c}$ is confirmed according to the actual situation of watershed [11].

3.2.2. Rainstorm-Flood Methodology. The discharge of debris flow was also calculated by the methodology of rainstormflood to analyze the discharge amplification under the condition that the impacts of block and outburst induced by deposit bodies or natural dams were considered. The formulae are shown as follows [11-13]:

$$
\begin{gathered}
Q_{C}=(1+\varphi) Q_{B} q, \\
\varphi=\frac{\left(\gamma_{D}-1\right)}{\left(\gamma_{H}-\gamma_{D}\right)} .
\end{gathered}
$$

In the formula (3), $Q_{C}$ is the peak discharge of debris flow and $Q_{B}$ is the peak discharge of flash flood, which is calculated by the parameters of the watershed using the methodology that was represented by the calculation handbook for rainstorm-flood at watersheds of Sichuan Province [14]. $\varphi$ indicates the correctional coefficient of debris flow, which is calculated by formula (4). $q$ is the amplification coefficient of debris flow, which is confirmed according to the situation of channel blocks [10]. $\gamma_{D}$ is the density of debris flow, which was obtained by formula (1), and $\gamma_{H}=2.65 \mathrm{t} / \mathrm{m}^{3}$ is the density of solid in debris flow.

\section{Debris Flows Distribution and Characteristics}

4.1. Debris Flow Distribution. On August 18, 2012, debris flows occurred in over 100 watersheds, gullies, and slopes and almost covered the whole basin, more than 10 landslides appeared at the slopes along Jushui River, and 3 dammed lakes were produced by debris flows and landslides. In July 9,2013 , debris flows mainly occurred in watersheds and the upper part of Jushui River as shown in Figure 2. Moreover, except for Ganhe watershed, debris flows reoccurred in all watersheds in 2013. 


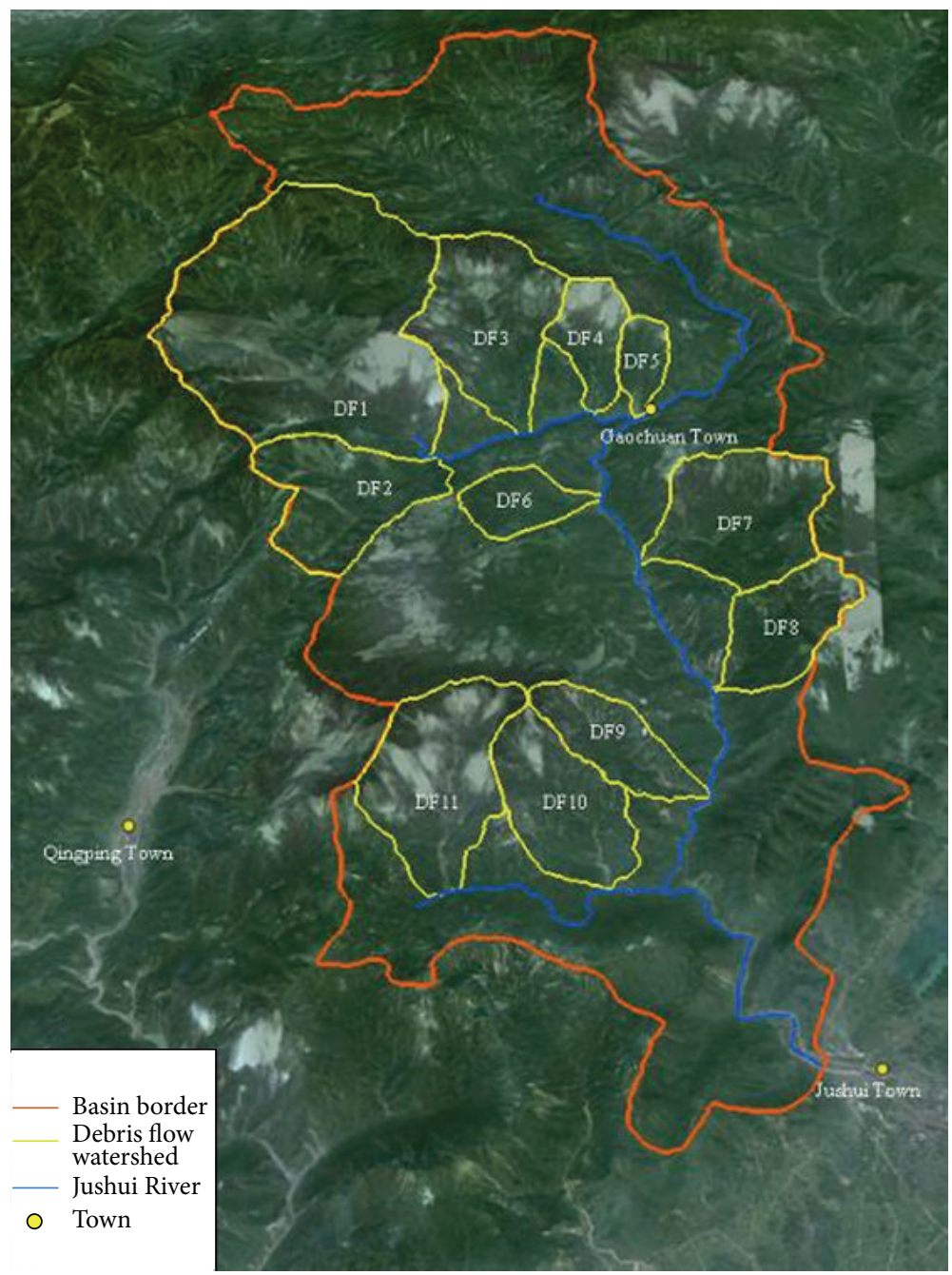

Figure 2: Distribution of debris flow watersheds (DF1: Laoyingyan, DF2: Sancha watershed, DF3: Mofang watershed, DF4: Chayuan watershed, DF5: Tangfang watershed, DF6: Dongzi watershed, DF7: Gan watershed, DF8: Ganhe watershed, DF9: Daoxi watershed, DF10: Daheba watershed, and DF11: Ouyangguan watershed).

\subsection{Debris Flow Characteristics}

4.2.1. High Density and Low Viscosity. According to the data of samples analysis and density of 14 debris flow deposits, debris flows were characterized by high density and low viscosity as shown in Table 1 . The test data of particle sizes from 14 deposit samples indicted that the fine materials of less than $0.05 \mathrm{~mm}$ and $0.005 \mathrm{~mm}$ were only about $0.2 \sim 5.5 \%$ and $0.1 \% \sim 1.2 \%$, respectively, and that larger $2 \mathrm{~mm}$ was almost over $74 \%$. The boulders with more over $1 \mathrm{~m}$ occupied about $2 \sim 5 \%$ and over $10 \%$ and $6 \sim 8 \%$ at the watersheds of Ganhe, Gan, and Chayuan, respectively. The density of debris flows calculated by the formula (1) ranged from 1.68 to $2.03 \mathrm{t} / \mathrm{m}^{3}$.

4.2.2. Large Discharge and Magnitude. The discharges of debris flows which were calculated by the method of discharge cross-section and rainstorm-flood were shown in Tables 2 and 3. Table 2 indicated that the discharges of debris flows at 8 watersheds varied from $62.2 \mathrm{~m}^{3} / \mathrm{s}$ to $552.5 \mathrm{~m}^{3} / \mathrm{s}$, which were higher than those before the Wenchuan Earthquake as shown in Table 3. Even if comparing to those under that condition of rainstorm with the probability of $0.2 \%$, with $100 \mathrm{~mm}$ rainfall per hour, the discharges of debris flows were also increased 1.20 6.5 times. Moreover, the discharge of debris flow at the Tangfang watershed also approached 2.2 times that before the Wenchuan Earthquake although the majority of debris flow materials had been blocked by step dams. Furthermore, the magnitude of debris flows also increased remarkably and ranged from 100,000 to $250,000 \mathrm{~m}^{3}$ at 8 watersheds with the sediment delivery modulus from 1.0 to $9.4 \times 10^{4} \mathrm{~m}^{3} / \mathrm{km}^{2}$. Moreover, the slope debris flows also delivered massive of sediments, over $50000 \mathrm{~m}^{3}$, and blocked Jushui River completely and partly, for example, those at Xinqiao Village and Lijiashan.

4.2.3. Hazard Chain. Many debris flows, especially the largescale ones, generally formed a hazard chain, involved in flash flood, debris flow, dammed lake, and outburst flood. 
TABLe 1: Particle size components and density of debris flow.

\begin{tabular}{lcccc}
\hline Watershed name & $P_{2}(\%)$ & $\begin{array}{c}P_{0.05} \\
(\%)\end{array}$ & $\begin{array}{c}P_{0.005} \\
(\%)\end{array}$ & $\begin{array}{c}\gamma_{D} \\
\left(\mathrm{~g} / \mathrm{cm}^{3}\right)\end{array}$ \\
\hline Tangfang & 81.1 & 1.7 & 0.2 & 1.89 \\
Sancha & 76.5 & 1.1 & 0.2 & 1.81 \\
Sancha $^{*}$ & 75.7 & 3.3 & 0.4 & 1.95 \\
Shuimo & 71.6 & 1.0 & 0.1 & 1.79 \\
Shuimo $^{*}$ & 75.1 & 0.3 & 0.1 & 1.70 \\
Chayuan & 76.9 & 4.1 & 1.2 & 2.03 \\
Dongzi & 86.3 & 0.6 & 0.1 & 1.79 \\
Dongzi & 89.5 & 0.2 & 0.1 & 1.68 \\
Xinqiao & 79.5 & 3.0 & 0.7 & 1.97 \\
Gan & 90.2 & 0.4 & 0.1 & 1.77 \\
Gan ${ }^{*}$ & 76.8 & 1.1 & 0.2 & 1.81 \\
Ganhe & 84.1 & 2.2 & 0.3 & 1.94 \\
Daoxi & 74.4 & 5.5 & 0.8 & 2.03 \\
Daoxi* & 75.5 & 0.6 & 0.1 & 1.76 \\
\hline
\end{tabular}

Notes: ${ }^{*}$ indicates that the samples and data were from the debris flows on July 9, 2013, and others were on August 18, 2012.

The debris flows from the watersheds of Sancha, Gan, Shuimo, Chayuan, and Xinqiao Village completely block Jushui River and produced dammed lakes and outburst flood. The outburst flood inundated Xinqiao Villages and about 400 persons were endangered. Furthermore, some debris flows blocked partially Jushui River and exacerbated flood due to the rise of water level and embankment collapses.

4.2.4. Channel Rapid Rise. Quantity of sediment transportation induced by debris flows rise Jushui River channel not only in some sites but also in whole. Numerous-occurrence debris flows resulted in river channel rising $1-2 \mathrm{~m}$ in average at most sections and even 3-4 m at some sections in 2012, for example, the channels at the outlets of the watersheds of Laoyingyan, Gan, and Ganhe and the river channel of Gaochuan Town upstream. Most river channel continuously rapidly rose in the process of the debris flows on July 9, 2013 (Figure 3), and the highway along river channel was buried. The hyperconcentrated and high-level flood caused by debris flows was characterized by higher-destruction capability and larger hazard zone and made more losses. Moreover, the river channel rise seriously endangered the securities of the first terraces at some sections, for example, Xinqiao Village, Maliuping terrace, and Quanshui Village.

4.2.5. Flood Amplification. The flood in Jushui River was magnified significantly by virtue of the combination of torrent flow and intensive sediment transportation. Flood level at the mainstream of Jushui Rive was higher $1 \sim 2 \mathrm{~m}$ than flow level at 4 sites of due to channel rise (Table 4 ), and even the higher approached $3 \sim 4 \mathrm{~m}$ at some river block sites although the discharges were less than those estimated. The peak discharges were $715 \mathrm{~m}^{3} / \mathrm{s}, 627 \mathrm{~m}^{3} / \mathrm{s}, 1056 \mathrm{~m}^{3} / \mathrm{s}$, and $1855 \mathrm{~m}^{3} / \mathrm{s}$ from upstream to downstream, respectively.

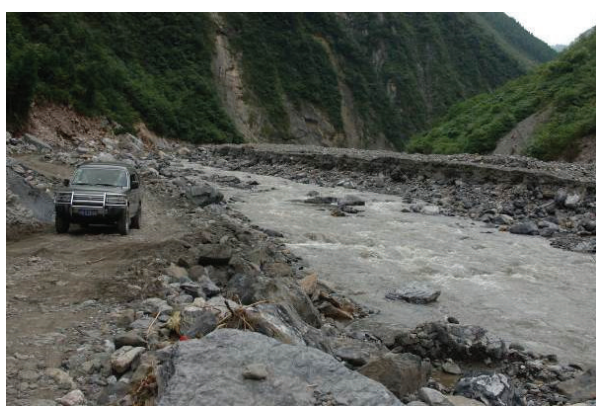

FIgURE 3: Channel rise at the upper part of Jushui River (after July 9, 2013, channel rose about 4 7 $\mathrm{m}$ compared to before and highway was buried and destructed).

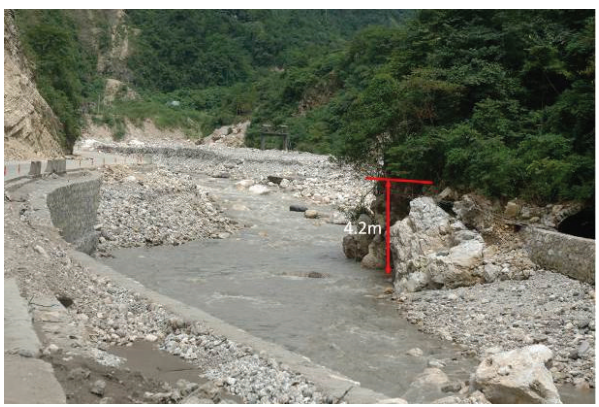

FIGURE 4: Flood amplification induced by river channel rise at Ganhe watershed outlet section in 2013.

Due to the combination impacts of flow level rise and the sediments delivered by flood, especially the gravels and boulders, flash flood submerged and destructed more river banks, farmlands, highways, and buildings, for example, the river section of Ganhe watershed (Figure 4).

\section{Damages of Debris Flows}

5.1. Debris Flow Burying. Debris flows generally deposit at the outlet of watersheds and the foot of slopes and bury houses, buildings, constructions and farmland, and so forth. Most of buildings and houses at Gaochuan Town in the right bank of Jushui River were silted up by the debris flow of Tangfang watershed and most of the houses of Xinqiao Village were also filled by debris flow deposits in 2012. Some houses and buildings of Chayuan village and the mine and buildings at the outlet of Laoyingyan watershed were buried in 2013 (Figure 5). Debris flows from slopes and gullies also buried and blocked the highway from Gaochuan to Jushui over 20 sites in 2012. Moreover, channel rapid rise induced by debris flows buried some constructions and land along river channel.

5.2. Debris Flow Scouring. Debris flow also intensively scoured and breached dams, watershed channels or drainage slots, and exacerbated hazards. The drainage slots of Shuimo watershed, Tangfang watershed, Gan watershed, and Ganhe watershed were intensively scoured and destructed to different extent and even lost their function in 2012. Debris 
TABLE 2: Discharges and volume of debris flows.

\begin{tabular}{|c|c|c|c|c|c|c|c|}
\hline Watershed name & $W_{c} / \mathrm{m}^{2}$ & $H / \mathrm{m}$ & $I / \%$ & $V_{c} / \mathrm{m} / \mathrm{s}$ & $Q_{c} / \mathrm{m}^{3} / \mathrm{s}$ & Volume $/ 10^{4} \mathrm{~m}^{3}$ & Delivery modulus $/ 10^{4} \mathrm{~m}^{3} / \mathrm{km}^{2}$ \\
\hline Sancha & 51 & 3 & 3 & 3.6 & 183.7 & 20 & 2.4 \\
\hline Shuimo & 50 & 2.5 & 10 & 4.1 & 205.9 & 10 & 1.0 \\
\hline Chayuan & 34.5 & 1.8 & 8 & 4.2 & 144.4 & 35 & 9.4 \\
\hline Tangfang & 15 & 1.5 & 11 & 4.1 & 62.2 & 15 & 9.1 \\
\hline Dongzi & 22.5 & 2.5 & 7 & 4.9 & 109.7 & 10 & 3.0 \\
\hline Gan & 75 & 3.2 & 4 & 4.3 & 325.7 & 25 & 3.0 \\
\hline Ganhe & 84 & 3 & 10 & 6.6 & 552.5 & 11 & 2.2 \\
\hline Daoxi & 42 & 4 & 9 & 7.6 & 319.4 & 13 & 6.5 \\
\hline
\end{tabular}

Notes: the data were those of debris flows on August 18, 2012.

TABLE 3: Debris flow discharges at different probabilities.

\begin{tabular}{lccccc}
\hline \multirow{2}{*}{ Watershed name } & \multicolumn{5}{c}{ Probability (\%) } \\
& 5 & 2 & 1 & 0.5 & 0.2 \\
\hline Sancha & 84.4 & 101.9 & 115.3 & 128.1 & 144.9 \\
Shuimo & 96.9 & 118.3 & 134.7 & 150.5 & 171.2 \\
Chayuan & 31.8 & 38.5 & 43.7 & 48.6 & 55 \\
Tangfang & 16.4 & 19.8 & 22.4 & 24.8 & 28 \\
Dongzi & 33.6 & 40.6 & 46 & 51.2 & 58 \\
Gan & 81.8 & 99.9 & 113.8 & 127.3 & 145 \\
Ganhe & 47.7 & 58.2 & 66.2 & 74 & 84.1 \\
Daoxi & 28.6 & 34.7 & 39.4 & 43.9 & 49.8 \\
\hline
\end{tabular}

Note: the data of Table 3 were probable discharge under the conditions of different rainfall intensity (probability), which were calculated and estimated according to the methodology of rainstorm-flood and not actual occurrence discharge using the geomorphologic parameters including areas, length, and slope gradient of channel.

TABLE 4: Flood level and flood discharge at the typical sites.

\begin{tabular}{lccc}
\hline Site name & \multicolumn{2}{c}{$\begin{array}{c}\text { Flood level }(\mathrm{m}) \\
\text { Flow and } \\
\text { channel rise }\end{array}$} & $\begin{array}{c}\text { Flood peak } \\
\text { discharge } \\
\left(\mathrm{m}^{3} / \mathrm{s}\right)\end{array}$ \\
\hline Sancha watershed outlet & 3.0 & $4.5 \sim 5.0$ & 715 \\
Gaochuan town upper & 2.1 & $3.0 \sim 3.5$ & 627 \\
Gaochun town & 2.0 & $3.0 \sim 3.5$ & 1056 \\
Gan watershed outlet & 2.4 & $4.0 \sim 4.5$ & 1855 \\
\hline
\end{tabular}

* The peak discharge was calculated by the area and the velocity of the surveyed cross-sections, and the velocities were figured out using Manning formula. These data expressed the situation of hazard events on August 18, 2012.

flow intensively scoured and impacted the drainage slots of Tangfang watershed so that the slot bases were even completely destructed at local sections. The storage dams and drainage slot in the Chayuan watershed were breached by large-scale debris flows in 2013. The debris flows of Sancha watershed intensively scoured channel and made the houses along channel in high-danger situation (Figure 6). Moreover, debris flow and hyperconcentrated flood intensively eroded river embankment so that they destructed highway base and

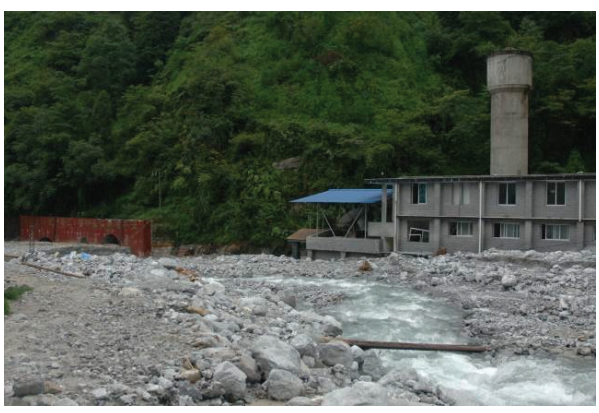

FIGURE 5: Laoyingyan debris flow buried mine and building (after July 9, 2013).

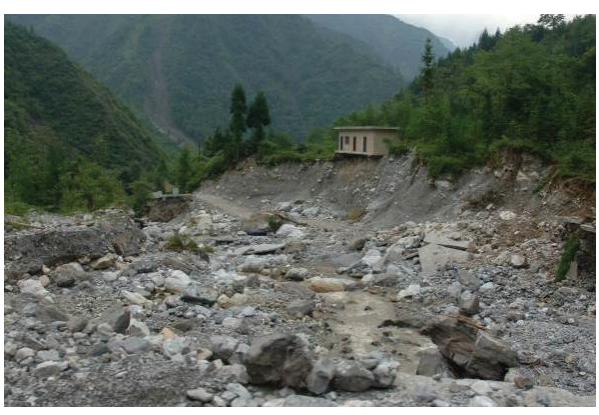

FIGURE 6: Debris flow of Sancha watershed scouring channel and endangering houses (after July 9, 2013).

produced outburst flood by virtue of embankment breach, for example, the upper part of Gaochuan Town.

5.3. Flood Inundation. The outburst flood induced by debris flows and high-level flood caused by river channel rise inundated many things. The outburst flood of debris flow dammed lake destructed about $170 \mathrm{~m}$ river embankment, rushed into Xianqiao Village, and submerged the first floor and second floor of most buildings. As a result, over 400 persons were homeless or lost their shops and properties in 2012 (Figure 7). The high-level flood from Laoyingyan and Sancha watershed overflowed river channel and submerged highway in July 2013, resulting in over 1000 persons being 


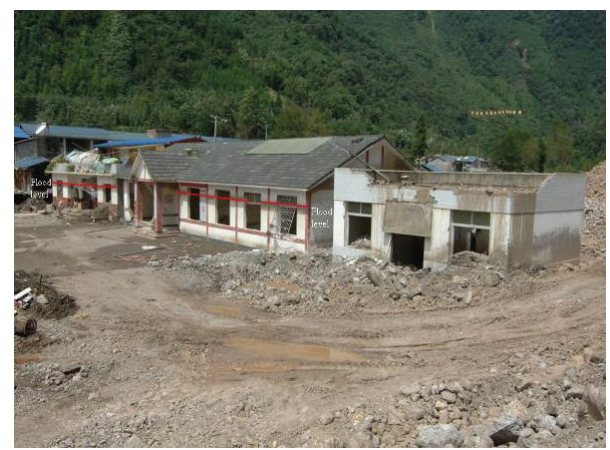

Figure 7: Outburst flood of debris flow dammed lake submerged Xinqiao Village in 2012.

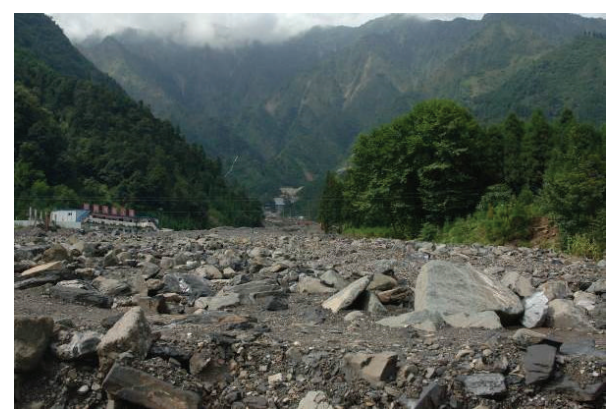

FIGURE 8: Large-scale debris flow of Chayuan watershed buried drainage slot and the whole deposition area in 2013.

isolated. Moreover, many other sites also were inundated by flood to different extent.

\section{Problems of Debris Flow Control}

6.1. Potential Debris Flows. Potential debris flows are a difficult problem of hazard prevention. Due to intensive disturbance of the Wenchuan Earthquake, quantities of cracked and unstable slopes, which are prone to form debris flows by intensive rainfall triggering, distribute in Jushui River basin but are very difficult to identify by field investigation and remote sense image interpretation, especially those in steep landform that human could not reach. These potential hazard sites posed significant difficulty and uncertainty on hazard prevention.

6.2. Overstandard Debris Flow. After the Wenchuan Earthquake, debris flows were featured by low triggering rainfall, large discharge, big magnitude, intensive destructing, and overstandard of present national control. As a result, many measures and techniques, which excel in normal debris flow control, could not regulate and control the process of the large debris flows following the Wenchuan Earthquake, for example, Tangfang watershed, Dongzi watershed, and Chayuan watershed (Figure 8). For these overstandard debris flows, the control measures should be designed and optimized according to the characteristics and change of debris flow but not the national regulation. Moreover, structure,

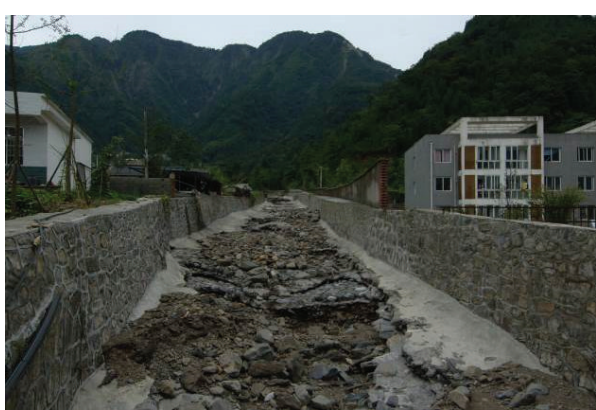

FIGURE 9: Destructed drainage slot in Tangfang watershed.

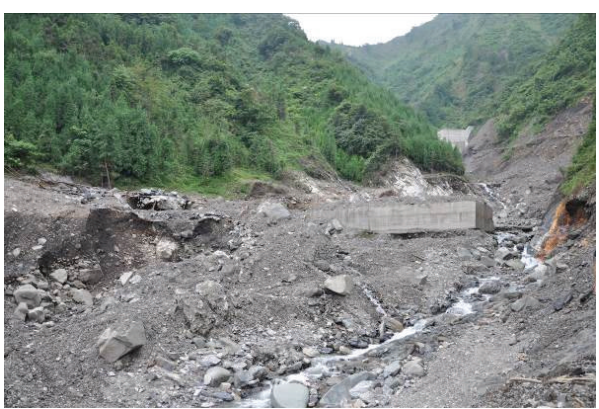

Figure 10: Debris flows filled in and breached sediment storage dams at the upper parts of Chayuan watershed in 2013.

materials, resistant capillarity, and building techniques of control constructions should be innovated and strengthened to resist the intense impacts of debris flow. For example, the substitute from mortar rubble masonry to armoured concrete was probably a good choice.

6.3. Control Construction Destruction. The destruction of control constructions of debris flows is a hard nut to crack in Jushui River basin and even the whole striken areas by Wenchuan Earthquake. The debris flow, on August 18, 2012, filled in the storage dam, which was justly constructed in May 2012 at Tangfang watershed and also broke discharge slot (Figure 9). The debris flows on July 9, 2013, also filled in some dams and breached discharge slots at Chayuan watershed (Figure 10). Investigation showed that most drainage slots for debris flows were buried due to overflows and lost their functions. It become a crucial issue that how to revise and recover these constructions to control subsequent debris flows.

6.4. Channel Rise. River channel rapid rise posed heavy threats on the mitigation of debris flow and flash flood. In 2012 and 2013, the channels of some sections along river, especially the upper parts of this basin, approached and even were higher than highway and villages, which were submerged. Due to active debris flows and flash flood, the whole basin will face the danger of river channel rapid rise. Maybe there will be a solution that regulates sediment distribution and relocates sediment by human activity along 
river, but necessitates considering how to and where to relocate a mass of sediment.

\section{Prevention of Debris Flows}

Due to abundant loose soil accumulation and unstable slopes, debris flow and its following hazards will be very active in the future 10 years at least and even longer time $[1,7]$. They are also remarkable difference to those that are not affected and disturbed by intense earthquake. For low triggering conditions, high-frequent reoccurrence, large discharges, and numerous-occurrences of debris flows, the following countermeasures are represented for the whole basin and dangerous watersheds.

\subsection{Jushui River Basin}

7.1.1. Potential Hazard Sites Identifying and Assessment. The identification of the potential hazard sites including unstable slopes, landslides, and debris flows contributes to the prevention and control of hazards. It is strongly suggested to be implemented by field investigation and remote sense image interpretation before rainfall seasons per years or after catastrophic hazards because that local environment is very vulnerable and geohazards are very active. Moreover, the assessment of hazard and risk must be made to classify the areas of safety, hazard, and high hazard for mitigating and reconstructing. For the high-hazard areas, the suggestions and emergency plans of mitigation should be made and practiced.

7.1.2. Inhabitants Relocating. The inhabitants at the dangerous areas of debris flows and flash floods should be considered to relocate due to long active period of geohazards. The inhabitants at the low terrace suffering flood inundating were recommended to relocate in priority because they will be threatened continuously by debris flow, flash flood, and channel rise. Moreover, the families and houses near debris flow watershed are suggested to be apart from the dangerous areas.

7.1.3. Monitoring and Alarming Network. Considering numerous-occurrence of debris flows after the Wenchuan Earthquake, the real-time monitoring and alarming network based on disastrous hazard sites and triggering conditions of hazards is the preference for hazard mitigation of debris flows and flash flood. This network should be featured with dynamic motoring of triggering conditions, data collection, transmission and share in real-time, professional analysis, as well as decision and alarming information addressing.

7.1.4. Emergency Mitigation Plan. The emergency plans for hazards mitigating including alarming, refuging, succoring, and reconstructing are strongly suggested to be established and improve the capabilities of hazards prevention of local people. And the emergency plans are required to be built in community unit and form mitigation network, which not only inspire the activities of local people but also exert the functions of local governments.

7.1.5. River Channel Renovating. Considering the whole rise of Jushui River channel induced by debris flows and flash flood, channel renovating becomes very necessary. The sediment in river channel, especially at the section with low terrace, should be dredged and relocated to keep rational channel for the discharge of flood and subsequent debris flows. Moreover, the sediment should be prohibited to initiate debris flow and to delivered by flood again. Therefore, sediment not only should be relocated in low hazard areas, but also had better be used in land reclamation or as the materials of building industry to reduce the pressure of river channel renovating.

7.2. Catastrophic Debris Flow Watershed Control. The debris flows at dangerous watersheds and gullies are featured by massive loose soil accumulation and steep-unstable slopes, big discharge, large magnitude, and high-frequency reoccurrence. They generally exceed the national standard of debris flow control and produced hazard chains, deteriorating hazards and losses. In order to efficiently mitigate debris flow hazards and reduce losses, the integrated control measures, with three functions of rationally relocating loose soil distribution, regulating discharges of debris flows, and decreasing the magnitude of debris flow to prevent hazard chain forming, are strongly suggested to be carried out referencing to the previous successful modes for mega ones as shown in Figure 11.

(1) The appropriate control measures should be rationally assigned in the areas of material source, formation, transportation, and deposition to recollocate loose soil in the whole watershed and regulate velocity and discharge of debris flows. As a result, the deposits into mainstream will be rationally controlled to prevent debris flow blocking river, dammed lake forming, and outburst flood producing.

(2) In the source areas, the measures for fixing soil including vegetation natural recovery, soil conservation, and prohibiting human disturbance are encouraged to be carried out to control surface soil erosion and increase the stability of slope and landslides. Moreover, the identified surface crack in slope should be filled up to prevent landslide or slope debris flow initiating and forming.

(3) In the formation areas, step-check dams are preferred to be built for controlling debris flow initiating. The quantity and size of dam will be designed and built according to channel slope gradient and loose soil volume. In order to efficiently separate surface flow and loose soil to control soil failure and prevent debris flow initiating, the gaps must be built in check dams to drain in time and reduce soil water pressure. Moreover, considering the characteristics of loose soil, the check dams are strongly built by concrete or 


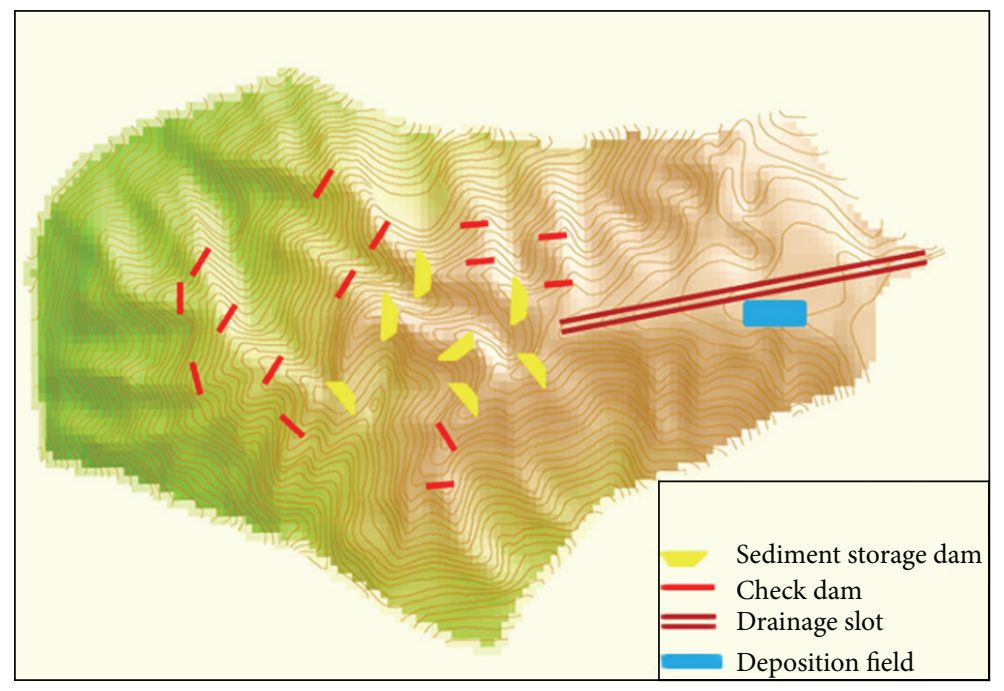

FIGURE 11: Debris flow control scheme of Chayuan watershed.

armoured concrete to increase the resistant capability of check dam and prevent its destructing.

(4) In the transportation areas, the step storage dams must be constructed to control sediment transporting and regulate the discharge of debris flow. The numbers and sizes of dams depend on the slope gradient of channel, geomorphology, and the probable magnitudes of debris flows. The necessary gaps should be designed and built in the dams to separate surface flow, stones and sediment according to the particle size component of loose soil and the peak discharge of flood, which will reduce the impacting and destructing powers of debris flow on dams. Moreover, the base and abutment of dams had better be located in bedrocks to consolidate dams and improve their stability. Additionally, for some steep or unstable slopes, the protection walls along channel will be a good measure to keep them stable and prevent them from replenishing debris flow.

(5) In the deposition areas, the drainage slot, whose discharge threshold was designed and built referencing to the regulated peak discharge of debris flow and the capability of sediment delivery of Jushui River, is built to drain debris flow and protect deposition areas. The accessorial instruments for kinetic energy dissipation should be constructed to reduce slot breach induced by debris flow. Moreover, if necessary, the appropriate deposition field for debris flow is also assigned to dispose and deposit the part that exceeds the drainage of drainage slot to protect other areas.

Besides, the prevention of watershed debris flows had better select, optimize, and assign the above feasible measures to control debris flows according to local situation. Moreover, the prevention will be made at a felicitous time to avoid reconstructing due to their destructing, and the existing control constructions are strongly suggested to be utilized, strengthened, or revised to meet the new requirements.

\section{Conclusions}

The debris flows, on August 18, 2012, and July 9, 2013, in Jushui River, were characterized by the clay soil content of $0.1 \sim 1.2 \%$, the density of $1.68 \sim 2.03 \mathrm{t} / \mathrm{m}^{3}$, the discharges of $62.2 \mathrm{~m}^{3} / \mathrm{s}$ to $552.5 \mathrm{~m}^{3} / \mathrm{s}$, and the sediment delivery modulus of $1.0 \sim 9.4 \times$ $10^{4} \mathrm{~m}^{3} / \mathrm{km}^{2}$. They also numerously reoccurred and produced hazard chain, involving in flash flood, debris flow, dammed lake, and outburst flood. The intense sediment transportation induced by debris flows also results in the rapid and continuous rise of river channel and flood amplification. The hazards and losses mainly originated from the burying and scouring of debris flows, flood inundating, and channel rapid rise. The prevention of debris flows is facing the intractable problems including potential hazard identification, overstandard debris flow, control construction destructing, and river channel rapid rise. Considering these problems, the prevention measures for Jushui River basin, including hazard identification and risk assessment, inhabitants relocating, monitoring and alarming network establishing, emergency plan founding, and river channel renovating, and the integrated control mode for debris flow watershed based on the regulating of the process of debris flow discharge, were recommended for debris flow mitigation.

\section{Conflict of Interests}

The authors declare that there is no conflict of interests regarding the publication of this paper.

\section{Acknowledgments}

This work was jointly supported by National Key Technologies R\&D Program of China (2012BAK10B04) and National 
Natural Science Foundation Program (41171012). The authors are very grateful for the help of the other colleagues from the Institute of Mountain Hazards and Environment, Chinese Academy of Sciences.

\section{References}

[1] P. Cui, J. Q. Zhuang, X. C. Chen et al., "Characteristics and countermeasures of debris flow in Wenchuan area after the earthquake," Journal of Sichuan University, vol. 42, no. 5, pp. $10-$ 19, 2010.

[2] Y. You, J. F. Liu, X. C. Chen et al., "Debris flow and its characteristics of Subao River in Beichuan County after 5.12 Wenchuan earthquake," Journal of Mountain Science, vol. 28, no. 3, pp. 358-366, 2010.

[3] C. Tang, J. Zhu, W. L. Li et al., "Rainfall-triggered debris flows following the Wenchuan Earthquake," Bulletin of Engineering Geology and the Environment, vol. 68, pp. 187-194, 2009.

[4] Q. Xu, S. Zhang, and W. L. Li, "The 13 August 2010 catastrophic debris flows after the 2008 Wenchuan earthquake, China," Natural Hazards and Earth System Sciences, vol. 12, pp. 201-216, 2012.

[5] X. J. Guo, P. Cui, L. Z. Xiang et al., "Research on the debris flow hazards in Gaojia watershed and Shenxi watershed in 2011," Journal of Catastrophology, vol. 27, no. 3, pp. 81-85, 2012.

[6] Y. G. Ge, G. H. Song, C. X. Guo et al., "Characteristics and causes of 8.18 debris flow hazards at the Longmenshan Town, Pengzhou, Sichuan," Journal of Hydraulic Engineering, vol. 43, supplement 2, pp. 147-154, 2012.

[7] P. Cui, X. Q. Chen, Y. Y. Zhu et al., “The Wenchuan Earthquake (May 12, 2008), Sichuan Province, China, and resulting geohazards," Natural Hazards, vol. 56, pp. 19-36, 2011.

[8] N. P. Ju, W. L. Hou, J. Zhao et al., "Geohazards of Jushui River in the Wenchuan earthquake area," Journal of Mountain Science, vol. 28, no. 6, pp. 732-740, 2010 (Chinese).

[9] B. Yu, "Research on the calculating density by the deposit of debris flows," Acta Sedimentologica Sinica, vol. 26, no. 5, pp. 789-796, 2008 (Chinese).

[10] B. F. Zhou, D. J. Li, D. F. Luo et al., Guide of Debris Flow Control, Science Press, Beijing, China, 1991 (Chinese).

[11] J. S. Wu, L. Q. Tian, Z. C. Kang et al., Debris Flow and Its Comprehensive Control, Science Press, Beijing, China, 1991 (Chinese).

[12] B. X. Tang, B. F. Zhou, J. S. Wu et al., Debris Flow in China, The Commercial Press, Beijing, China, 2000 (Chinese).

[13] D. J. Li, Theory and Practice of Debris Flow Mitigation, Science Press, Beijing, China, 1997, (Chinese).

[14] Water and Electricity Department of Sichuan Province, Calculation Handbook of Flood Induced by Rainstorm at Watersheds of Sichuan Province, Chengdu, China, 1984. 

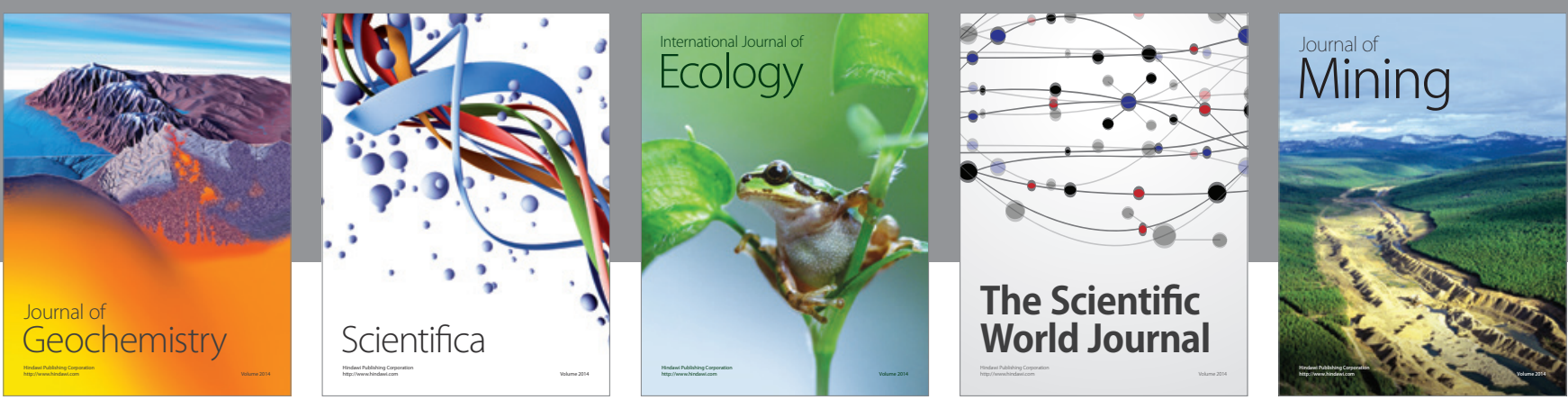

The Scientific World Journal
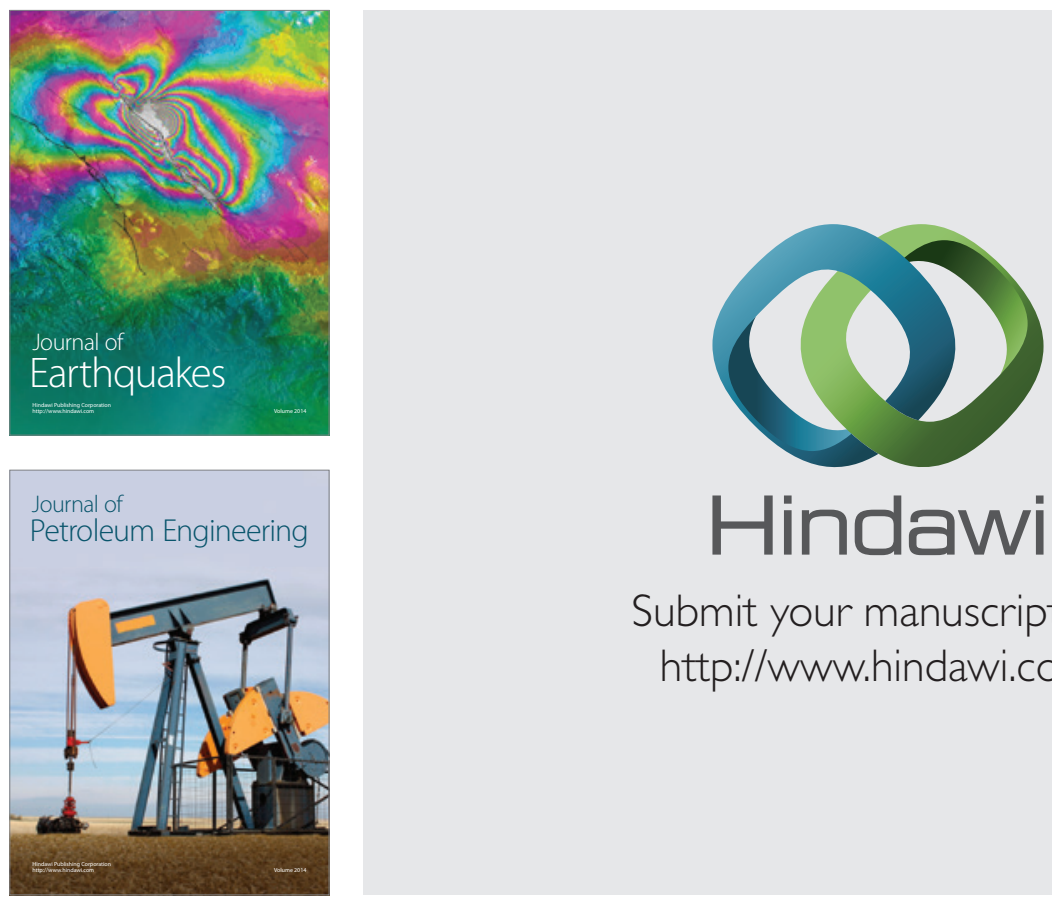

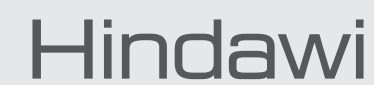

Submit your manuscripts at

http://www.hindawi.com
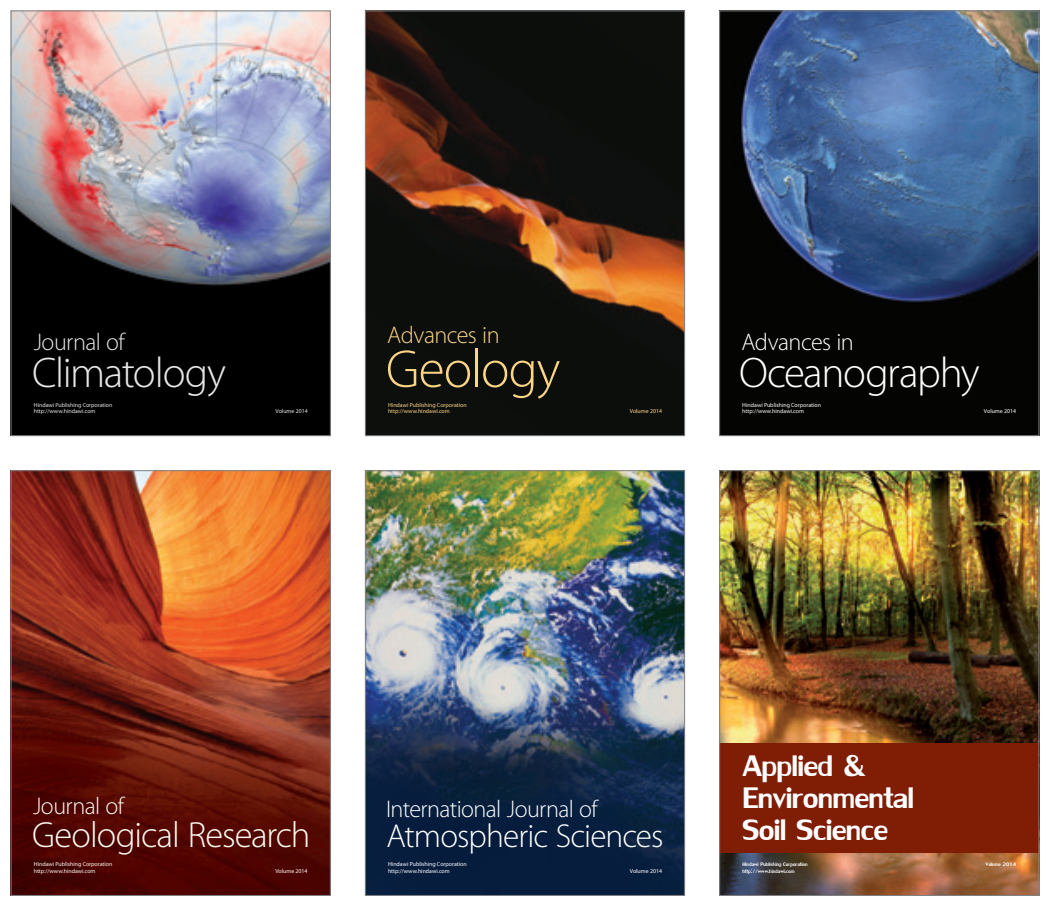
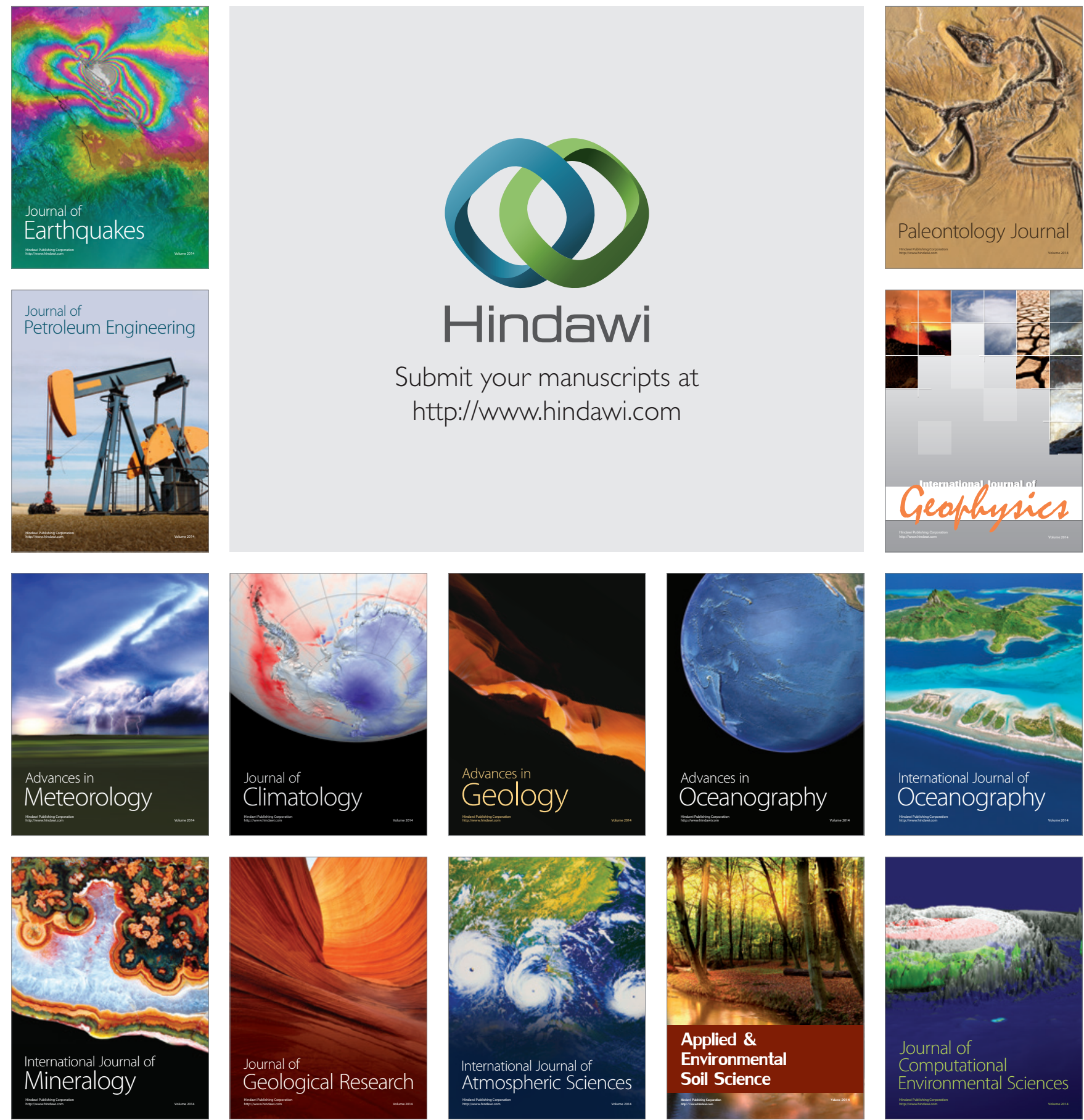